\title{
ENERGY EXPENDITURE IN STRENGTH TRAINING: A CRITICAL APPROACH ${ }^{1}$
}

\author{
Carlos Leandro Tiggemann
}

Faculdade da Serra Gaúcha, Caxias do Sul, Rio Grande do Sul, Brasil

\section{Ronei Silveira Pinto}

Universidade Federal do Rio Grande do Sul, Porto Alegre, Rio Grande do Sul, Brasil

\section{Matias Noll}

Universidade Federal do Rio Grande do Sul, Porto Alegre, Rio Grande do Sul, Brasil

Maira Cristina Wolf Schoenell

Universidade Federal do Rio Grande do Sul, Porto Alegre, Rio Grande do Sul, Brasil

\section{Luiz Fernando Martins Kruel}

Universidade Federal do Rio Grande do Sul, Porto Alegre, Rio Grande do Sul, Brasil

\begin{abstract}
Energy expenditure in strength training has been the subject of several studies over the last decades. However, the evaluated protocols present important and significant differences, making it impossible to compare them and reach definitive conclusions. The use of work units (sets $\mathrm{x}$ repetitions $\mathrm{x}$ load), adding the exercise execution and recovery phase, seems to allow for a better for the understanding of energy expenditure in strength training, being that energy expenditure increases with increasing work level. This, together with the use of observed absolute values ( $\mathrm{kcal}$ or liters of $\mathrm{O}_{2}$ ) instead of relative values $(\mathrm{kcal} / \mathrm{min})$, may allow for a better understanding of the influence on different variables.
\end{abstract}

Keywords: Energy expenditure. Oxygen consumption. Resistance training. Weight training.

\section{Introduction}

Daily physical activity plays a decisive role in controlling the human anthropometric profile, especially regarding the distribution and accumulation of body fat. Energy expenditure (EE) produced by physical activity is the only intentional and non-pharmacological way of countering the effects of a hypercaloric intake, attempting to maintain a balance between daily energy expenditure and intake. Systematized and organized physical exercise, such as used in strength training (ST), can contribute to increase total EE. Although there are few studies on this subject, some authors have investigated the way in which different variables (load, sets, repetitions, etc.) can affect EE (MEIRELLES; GOMES, 2004; MATSUURA et al., 2006; NETO et al., 2009; PINTO et al., 2011). The aim of the present report was to discuss some methods adopted in these studies, and how they affect the results and practical applications.

\footnotetext{
${ }^{1} \mathrm{O}$ presente trabalho não contou com apoio financeiro de nenhuma natureza para sua realização.
} 


\section{Discussion topics}

\section{Evaluation of energy expenditure in strength training sessions}

There are no direct methods for measuring energy expenditure in humans. It can only be estimated by measuring body heat production (WILMORE; COSTILL, 2001). This estimation can be performed using different direct (calorimetric chamber), or indirect (gas exchange), measurement methods (POEHLMAN; MELBY, 1998). Due to its ease of application, the most commonly used method in ST studies is the respiratory gas exchange measurement, presenting an accuracy of -2 to $4 \%$. In this method, the consumption of one liter of oxygen $\left(\mathrm{O}_{2}\right)$ corresponds to an EE of $5.05 \mathrm{kcal}$ (MEIRELLES; GOMES, 2004).

Strength and aerobic exercise does not only have acute effects on the body, i.e., taking place during their execution. $\mathrm{O}_{2}$ consumption remains high for several minutes (15 min), or even hours (48 h), after the end of exercise, until partial or full homeostasis is reestablished. This extra $\mathrm{O}_{2}$ consumption is called excess post-exercise oxygen consumption (EPOC) (MEIRELLES; GOMES, 2004). It is important to understand that EPOC is an integral component of the total EE in an ST session, since its duration and magnitude is directly affected by the exercise acute phase. Analyzing EE and EPOC separately may therefore lead to wrongful interpretation of the results. In addition, relativizing the results to the duration of the session $(\mathrm{kcal} / \mathrm{min})$ can also lead to error, especially because it does not consider the EPOC. The $\mathrm{kcal} / \mathrm{min}$ ratio may be important to optimize the session duration, i.e., achieve the same $\mathrm{EE}$ in less time in different sessions. However, if all ST variables are equalized, and EPOC is added to EE, these differences disappear (HALTOM et al., 1999; KELLEHER et al., 2010).

Another methodological problem found in some studies refers to the period of EPOC evaluation, which is often shorter than needed for $\mathrm{O}_{2}$ consumption to return to the resting, or basal, level, leading to underestimation of the total EE for the training session. EE in ST is therefore often not measured continuously but at intervals (e.g., every $15 \mathrm{~min}$ ) (NETO et al., 2009). Similarly, EPOC may be overestimated if it is measured for long periods, since other factors may contribute to increased $\mathrm{O}_{2}$ consumption during its measurement period, such as the thermic effect of food. Even knowing that ST sessions may result in prolonged homeostasis breaks, methodological questions therefore prevent its effective evaluation, and researchers must rely on their good judgment to determine the duration of EPOC evaluation, considering that EPOC is usually negligible after 2 hours.

Depending on the protocol applied, the EE for a ST session can vary from 64 to 534 $\mathrm{kcal}$, and EPOC from 6 to $114 \mathrm{kcal}$ (MEIRELLES; GOMES, 2004), with a median of $41 \mathrm{kcal}$ and lasting up to 48 hours (NETO et al., 2009). Higher, and extreme, values have been reported, but were associated to external validation or methodological problems. These large variations mainly result from the use of different combinations of ST variables (sets, repetitions, load, interval, etc.) in different studies, resulting in substantial variations in volume and intensity, as will be discussed next.

\section{Determining factors of EE}

Basal metabolic rates are known to vary widely between different individuals, between 876 and $3728 \mathrm{kcal} /$ day (standard deviation: $315 \mathrm{kcal} /$ day) (BOUCHARD, 2003). This higher or lower energy use efficiency depends on several metabolic and hormonal factors, influenced by the genotype and phenotype of the individuals. Related to this question, a factor that can be 
considered to greatly affect the evaluation of EE during physical exercise is the amount of muscle mass.

The greater the muscle mass involved in the exercise, the higher the EE, being directly affected by gender, age and type of exercise. This relationship is supported by the higher absolute EE observed for men than for women, with these differences decreasing when EE is relativized to muscle mass or lean body mass (PHILLIPS; ZIURAITIS, 2003). In addition, comparing different ST exercises, EE is observed to be higher for lower limb than for upper limb and torso exercises (HICKSON et al., 1984), but lower than for aerobic exercises (BLOOMER, 2005). Regarding age, the effects of sarcopenia (muscle mass decrease) directly affect EE, resulting in lower EE for elderly than for younger individuals (PHILLIPS; ZIURAITIS, 2004).

However, this close relationship between muscle mass volume and EE seems to be contradicted by the fact that, in the long term, ST increases muscle mass but this does not result in a corresponding increase in EE (POEHLMAN; MELBY, 1998). Studies have observed that increased lean body mass $(\mathrm{LBM} ; \approx 1.6 \mathrm{~kg}$ ) following a training period did not result in significant changes in basal metabolism in young people $(1.29 \mathrm{vs} 1.30 \mathrm{kcal} / \mathrm{min}$; p > 0.05) (BROEDER et al., 1992), but the opposite was observed for elderly people (LBM increase of $\approx 7.7 \%$, and of EE increase from 1.54 to $1.67 \mathrm{kcal} / \mathrm{min} ; \mathrm{p}<0.01$ ) (PRATLEY et al., 1994). These differences were probably due to the higher sensitivity of elderly people to ST, especially of the sympathetic nervous system, hormonal changes (noradrenaline release), protein turnover, and metabolic activity (POEHLMAN; MELBY, 1998). Other methodological factors may also have affected these results, such as the inability of measuring small absolute changes, the inability of isolating the variable to be measured (EE), and the short training periods tested in the studies $(12-20$ weeks).

\section{Effect of acute ST and EPOC variables}

$\mathrm{ST}$ is constituted by volume variables, such as the number of different exercises, repetitions, sets and weekly sessions, and intensity variables, such as the amount of load, rest period between sets and exercises, exercise order, time of execution of each repetition, and type of contraction, being that all variables are directly linked (TAN, 1999). Increasing intensity, especially by increasing load or decreasing time of execution, inevitably results in decreased volume (number of repetitions per set, for example), making it difficult to compare different protocols. In order to analyze EE considering the different ST variables, two aspects need therefore be considered.

First, it must be understood that the energy used in any type of physical exercise is nothing more than chemical energy obtained from macronutrients (carbohydrates, fats and proteins) converted into mechanical energy (movement $=$ work), most of which being lost as thermal energy (heat). When ST variables are analyzed separately, e.g., the effect of load or of the number of repetitions, the amount of work (W) performed is not considered because $\mathrm{W}$ is the product of force (mass $\mathrm{x}$ acceleration) and load displacement (mass), and does not consider the relationship with the time of execution (KNUTTGEN; KRAEMER, 1987). Comparing two ST protocols (circuit vs traditional) considering only the number of sets and repetitions (2 x 20 vs 2 x 10), or only the load (50 vs $70 \% 1 \mathrm{RM}$ ), therefore does not allow a correct understanding of the real effect of these variables on EE. In the example cited above (PICHON et al., 1996), because higher EE was obtained for the first protocol $(53.4 \pm 20.8$ vs $49.8 \pm 22.6$; $\mathrm{p}=$ 0.032), it could be inferred that the use of lower load, or higher number of repetitions, resulted in higher EE. However, this is only true if the total amount of $\mathrm{W}$ performed, which was higher for the circuit protocol ( $2 \times 20 \times 50 \% 1 \mathrm{RM}$ vs $2 \times 10 \times 70 \% 1 \mathrm{RM})$, is used as criterion. It should also be considered that when the same exercises are used in different protocols, the 
same load displacement is obtained for the same number of repetitions, and it can therefore be inferred that a higher number of repetitions results in higher $\mathrm{W}$.

This is confirmed by the fact that different protocols equated by the total $\mathrm{W}$ present the same EE (BALLOR et al., 1989; THORNTON; POTTEIGER, 2002; KELLEHER et al., 2010). Furthermore, when the same load is used for a different number of sets or repetitions (different total volumes), EE increases with increasing volume (HENLEY et al., 2004). The use of different loads (75 vs $85 \%$ 1RM) for the same number of repetitions (for example, 5 repetitions) was observed to result in similar EE, which may be explained by the small differences in total $\mathrm{W}$ between protocols, resulting in undetectable differences (RATAMESS et al., 2007).

A similar understanding seems to apply to the remaining ST variables. Different times of execution of each repetition (speed) also do not result in different total caloric expenditure for different protocols equated by the total W (BALLOR et al., 1989; MAZZETTI et al., 2007). Even when very different times of execution were compared $(1+1 \mathrm{~s}$ vs $10+5 \mathrm{~s}$, for the concentric and eccentric phase, respectively), longer contraction times did not result in higher EE than for the protocol with highest W ( $2 \times 8 \times 65 \%$ vs $1 \times 8 \times 25 \% 1 \mathrm{RM})$. Regarding the order of exercises, protocols equated by the total $\mathrm{W}$ presented similar EE independently of the order of exercises (FARINATTI et al., 2009).

In addition, when protocols with different types of contraction were compared, protocols with concentric and eccentric contractions resulted in an increase of only $14 \%$ of total EE when compared to exclusively concentric protocols (for the same number of repetitions, sets and load) (DUDLEY et al., 1991). In order to better understand these results, it should be first understood that the force production capacity is higher in the eccentric than in the concentric phase. Therefore, for a given exercise, a $50 \mathrm{~kg}$ load may represent $100 \% 1 \mathrm{RM}$ for the concentric phase, but a higher load may be needed to achieve maximum force during the eccentric phase. This would explain the $14 \%$ decrease in total EE observed for the eccentric phase. This is confirmed by the fact that no differences are observed when EE for the two phases is compared in isokinetic evaluations, where force production is maximum for each phase (CARUSO et al., 2001).

Another aspect that should be considered is that the rest period between sets can affect EE, both during acute exercise and especially during EPOC. A characteristic of aerobic exercises is their continuous execution. When EE is evaluated during and following a training session (EPOC), there are therefore two well delimited moments, with EPOC being considered the recovery phase. This may be only partially accepted in ST because of its intermittence: each rest period between sets or exercises corresponds to a partial recovery, with total recovery only being achieved at the end of the training session. Analyzing only EPOC according to the different ST variables is therefore a mistake, since partial recoveries occur during the rest periods during the session, and are included in the session's EE.

The shorter the rest period between sets, the higher the training session intensity, many times requiring the decrease of another variable, such as load or number of repetitions, to enable the comparison between different protocols (RATAMESS et al., 2007). This allows to understand many pertinent questions existing in literature. The shorter rest periods (20 vs 60 s) characteristic of circuit training result in higher EPOC, due to higher difficulty of recovery between sets (MURPHY; SCHWARZKOPF, 1992; HALTOM et al., 1999). Haltom et al. (1999) compared two similar training protocols (2 circuits of 8 exercises with 20 repetitions performed at $75 \%$ of a previously determined 20 repetition maximum) with different rest periods ( 20 and $60 \mathrm{~s}$ ). The protocol with the shorter rest period took less time to complete (13 vs $23 \mathrm{~min}$ ), and presented higher EPOC (10.3 vs $7.4 \mathrm{~L} \mathrm{O}_{2} ; 1 \mathrm{~h}$ evaluation). However, it presented lower absolute EE for the training session (18.7 vs $\left.24.38 \mathrm{~L} \mathrm{O}_{2}\right)$, resulting in similar total EE. 
In a study comparing two protocols differing only in the number of sets (1 vs 3 ), similar $\mathrm{O}_{2}$ consumption during EPOC was observed for the two protocols $(22.3 \pm 5.0$ vs $22.5 \pm 8.0$ kcal). This was possibly due to the fact that both protocols used the same load (8 RMs) and rest period (90 s), enabling similar partial recovery between sets, with EPOC only being responsible for the final debit (HADDOCK; WILKIN, 2006). It should also be noted that total $\mathrm{EE}$ (sum of the training session and EPOC) was almost three times higher for the protocol with 3 sets $(661.9 \pm 43.9$ vs $234.7 \pm 13.4 \mathrm{kj})$.

Regarding load, although some authors support that EPOC increases with increasing load (MEIRELLES; GOMES, 2004), others do not agree (NETO et al., 2009). Once more, it is impossible to explain EPOC values based on only one variable, and a wider analysis is essential. Using the total $\mathrm{W}$ associated to the time interval is the most consistent method for this analysis, being impracticable to dissociate the EE for the training session and for EPOC. Neto et al. (2009) analyzed six studies using different loads, which according to the authors presented conflicting results. However, the results can be explained from a different perspective. The studies where lower loads resulted in higher EPOC responses also reported higher W (MURPHY; SCHWARZKOPF, 1992; KANG et al., 2005). For the protocols presenting similar EPOC, the variations in intensity and total $\mathrm{W}$ may have been very small and not measurable (RATAMESS et al., 2007), or the different loads were equated by total W (OLDS; ABERNETHY, 1993). Finally, for the protocols presenting higher EPOC response with higher loads, in one study the higher loads also resulted in higher W (HUNTER et al., 2003), and in the other the lowest intensity represented a very low load ( 2 x 15 x 45\% 8RMs), and the noncontinuous measurement during EPOC may have compromised the results (HUNTER et al., 2003).

\section{Final considerations}

Comparing training protocols considering the ST variables separately seems to be a mistake, because it seems impossible to dissociate them. The use of work units ( $\mathrm{W}=$ sets $\mathrm{x}$ repetitions $\mathrm{x}$ load), together with the sum of measurements for the execution and the recovery phase (EPOC), seems to be the most consistent approach to understand EE in ST, being that EE increases with increasing W. A better understanding of the effect of the different variables can therefore be achieved, possibly considering the absolute values observed ( $\mathrm{kcal}$ or $\mathrm{L}$ of $\mathrm{O}_{2}$ ) instead of relative values $(\mathrm{kcal} / \mathrm{min})$. The need of a rigorous methodological control should be highlighted, especially regarding the continuous measurement of EPOC until basal rates are resumed. It should also be highlighted that the acute EE during an ST session is small, and even considering its possible long term contribution by increasing lean body mass, its contribution is still not expressive (DONNELLY et al., 2009), and should be considered part of the total $\mathrm{EE}$ in daily physical activities.

\section{GASTOS ENERGÉTICOS EN LOS ENTRANAMIENTOS DE FUERZA: UN ENFOQUE CRÍTICO}

\section{Resumen}

El gasto energético en el entrenamiento de resistencia ha sido objeto de varios estudios en las últimas décadas. Sin embargo, los protocolos evaluados presentan diferencias importantes y significativas, por lo que es imposible compararlos y llegar a conclusiones definitivas. El uso de unidades de trabajo (conjuntos x repeticiones x carga), sumando la ejecución del ejercicio y la fase de recuperación, parece permitir una mejor comprensión del gasto energético en el entrenamiento de resistencia, siendo que el gasto energético aumenta con el nivel de trabajo. 
Ello, junto con el uso de valores absolutos observados (kcal o litros de $\mathrm{O}_{2}$ ) en lugar de valores relativos (kcal/ min), puede permitir una mejor comprensión de la influencia en diferentes variables.

Palabras clave: Gasto de energía. Consumo de oxígeno. Entrenamiento de resistencia. Entrenamiento con pesas.

\section{GASTOS ENERGÉTICOS NOS TREINAMENTOS DE FORÇA: UMA APROXIMAÇÃO CRÍTICA}

\section{Resumo}

O gasto energético no treinamento de resistência tem sido objeto de vários estudos nas últimas décadas. Todavia, os protocolos avaliados apresentam diferenças importantes e significativas, pelo que é impossível compará-los e chegar a conclusões definitivas. O uso de unidades de trabalho (conjuntos x repetições x carga), somando a execução do exercício e a fase de recuperação, parece permitir uma melhor compreensão do gasto energético no treinamento de resistência, sendo que o gasto energético aumenta com o nível de trabalho. Isso, junto ao uso de valores absolutos observados ( $\mathrm{kcal}$ ou litros de $\mathrm{O}_{2}$ ) em lugar de valores relativos ( $\mathrm{kcal} / \mathrm{min}$ ), pode permitir uma melhor compreensão da influência em diferentes variáveis.

Palavras-chave: Gasto de energia. Consumo de oxigênio. Treinamento de resistência. Treinamento com pesos.

\section{Referências}

BALLOR, D. L. et al. Energy output during hydraulic resistance circuit exercise for males and females. Journal of Applied Sport Science Research, v. 3, n., p.7-12. 1989.

BLOOMER, R. J. Energy cost of moderate-duration resistance and aerobic exercise. Journal of Strength and Conditioning Research, v. 19, n. 4, p. 878-82. 2005.

BOUCHARD, C. Atividade Física e Obesidade. São Paulo: Manole, 2003.

BROEDER, C. E. et al. The effects of either high-intensity resistance or endurance training on resting metabolic rate. American Journal of Clinical Nutrition, v. 55, n. 4, p. 802-10. 1992.

CARUSO, J. F. et al. An Isokinetic Investigation of Contractile Mode's Effect on the Elbow Flexors. Journal of Strength and Conditioning Research, v. 15, n. 1, p. 69-74. 2001.

DONNELLY, J. E. et al. Appropriate physical activity intervention strategies for weight loss and prevention of weight regain for adults. Medicine and Science in Sports and Exercise, v. 41, n. 2, p. 459-71. 2009.

DUDLEY, G. A. et al. Influence of eccentric actions on the metabolic cost of resistance exercise. Aviation Space and Environmental Medicine, v. 62, n. 7, p. 678-82. 1991.

FARINATTI, P. T. V. et al. Influence of exercise order on oxygen uptake during strength training in young women. Journal of Strength and Conditioning Research, v. 23, n. 3, p. 1037-44. 2009. 
HADDOCK, B. L.; WILKIN, L. D. Resistance training volume and post exercise energy expenditure. International Journal of Sports Medicine, v. 27, n. 2, p. 143-8. 2006.

HALTOM, R. W. et al. Circuit weight training and its effects on excess postexercise oxygen consumption. Medicine and Science in Sports and Exercise, v. 31, n. 11, p. 1613-8. 1999.

HENLEY, M. O. et al. Effect of single and multiple-set resistance exercise on postexercise energy expenditure [ABSTRACT]. Medicine and Science in Sports and Exercise, v. 36, n. 5, p. S277. 2004.

HICKSON, J. F. et al. Energy cost of weight training exercise. National Strength \& Conditioning Association Journal, v. 6 n. 5, p. 22-3. 1984.

HUNTER, G. R. et al. Comparison of metabolic and heart rate responses to super slow vs. Traditional resistance training. Journal of Strength and Conditioning Research, v. 17, n. 1, p. 76-81. 2003.

KANG, J. et al. Evaluation of physiological responses during recovery following three resistance exercise programs. Journal of Strength and Conditioning Research, v. 19, n. 2, p. 305-9. 2005.

KELLEHER, A. R. et al. The metabolic costs of reciprocal supersets vs. traditional resistance exercise in young recreationally active adults. Journal of Strength and Conditioning Research, v. 24, n. 4, p. 1043-51. 2010.

KNUTTGEN, N. H.; KRAEMER, W. J. Terminology and measurement in exercise performance. Journal of Applied Sport Science Research, v. 1, n., p.1-10. 1987.

MATSUURA, C. et al. Gasto energético e consumo de oxigênio pós- exercício contraresistência. Revista de Nutrição, v. 19, n. 6, p. 729-40. 2006.

MAZZETTI, S. et al. Effect of explosive versus slow contractions and exercise intensity on energy expenditure. Medicine and Science in Sports and Exercise, v. 39, n. 8, p.1291-301. 2007.

MEIRELLES, C. M.; GOMES, P. S. C. Efeitos agudos da atividade contra-resistência sobre o gasto energético: revistando impacto das principais variáveis. Revista Brasileira de Medicina do Esporte, v. 10, n. 2, p. 122-30. 2004.

MURPHY, E. and SCHWARZKOPF, R. Effects of standard set and circuit weight training on Excess post-exercise oxygen consuption. Journal of Applied Sport Science Research, v. 6, n. 2, p.88-91. 1992.

NETO, A. G. C. et al. Influênncia das Variáveis do Treinamento Contra-Resistência Sobre o Consumo de Oxigênio em Excesso após o Exercício: Uma Revisão Sistemática. Revista Brasileira de Medicina do Esporte, v. 15, n. 1, p. 70-8. 2009.

OLDS, T. S.; ABERNETHY, P. J. Postexercise oxygen consumption following heavy and light resistance exercise. Journal of Strength and Conditioning Research, v. 7, n. 3, p. 14752. 1993. 
PHILLIPS, W. T.; ZIURAITIS, J. R. Energy cost of the ACSM single-set resistance training protocol. Journal of Strength and Conditioning Research, v. 17, n. 2, p. 350-5. 2003.

Energy cost of single-set resistance training in older adults. Journal of Strength and Conditioning Research, v. 18, n. 3, p. 606-9. 2004.

PICHON, C. E. et al. Blood Pressure and Heart Rate Response and Metabolic Cost of Circuit Versus Traditional Weight Training. Journal of Strength and Conditioning Research, v. 10, n. 3, p. 153-6. 1996.

PINTO, R. S. et al. Respostas metabólicas ao treinamento de força: uma ênfase no dispêndio energético. Revista Brasileira de Cineantropometria e Desempenho Humano, v. 13, n. 2. 2011.

POEHLMAN, E. T.; MELBY, C. Resistance training and energy balance. International Journal of Sport Nutrition and Exercise Metabolism, v. 8, n. 2, p. 143-59. 1998.

PRATLEY, R. et al. Strength training increases resting metabolic rate and norepinephrine levels in healthy 50- to 65-yr-old men. Journal of Applied Physiology, v. 76, n. 1, p. 133-7. 1994.

RATAMESS, N. A. et al. The effect of rest interval length on metabolic responses to the bench press exercise. European Journal of Applied Physiology, v. 100, n. 1, p.1-17. 2007.

TAN, B. Manipulating Resistance Training Program Variables to Optimize Maximum Strength in Men: A Review. Journal of Strength and Conditioning Research, v. 13, n. 3, p. 289-304. 1999.

THORNTON, M. K.; POTTEIGER, J. A. Effects of resistance exercise bouts of different intensities but equal work on EPOC. Med Sci Sports Exerc, v. 34, n. 4, abr., p. 715-22. 2002.

WILMORE, J. H. and COSTILL, D. L. Fisiologia do Esporte e do Exercício. São Paulo: Manole, 2001.

Recebido em: 28/11/2016

Revisado em: 01/12/2016

Aprovado em: 23/03/2017

Endereço para correspondência:

matiasnoll@yahoo.com.br

Matias Noll

Universidade Federal do Rio Grande do Sul

Av. Paulo Gama, 110 - Bairro Farroupilha

Porto Alegre - Rio Grande do Sul

CEP: 90040-060 